\title{
LEGISLACIÓN DE DERECHO ADMINISTRATIVO
}

\author{
Fernando GONZÁLEZ BotIJA \\ Departamento de Derecho Administrativo \\ Facultad de Derecho \\ Universidad Complutense de Madrid \\ dp143@ucm.es
}

- Real Decreto-ley 16/2017, de 17 de noviembre, por el que se establecen disposiciones de seguridad en la investigación y explotación de hidrocarburos en el medio marino (BOE, núm. 280, de 18 de noviembre de 2017).

- Ley 9/2017, de 8 de noviembre, de Contratos del Sector Público, por la que se transponen al ordenamiento jurídico español las Directivas del Parlamento Europeo y del Consejo 2014/23/UE y 2014/24/UE, de 26 de febrero de 2014 (BOE, núm. 272, de 9 de noviembre de 2017).

- Real Decreto 920/2017, de 23 de octubre, por el que se regula la inspección técnica de vehículos (BOE, núm. 271, de 8 de noviembre de 2017).

- Real Decreto 953/2017, de 31 de octubre, por el que se dictan normas complementarias para la realización de las elecciones al Parlamento de Cataluña 2017 (BOE, núm. 267, de 3 de noviembre de 2017).

- Real Decreto 954/2017, de 31 de octubre, por el que se dispone, en virtud de las medidas autorizadas con fecha 27 de octubre de 2017 por el Pleno del Senado respecto de la Generalitat de Cataluña en aplicación del art. 155 de la Constitución, la adopción de diversas medidas respecto de la organización de la Generalitat de Cataluña y el cese de distintos altos cargos de la Generalitat de Cataluña (BOE, núm. 266, de 2 de noviembre de 2017).

- Orden INT/1038/2017, de 28 de octubre, por la que se dispone el cese de don Josep Lluís Trapero Álvarez en la plaza de la categoría de Mayor de la Escala Superior del Cuerpo de Mossos d'Esquadra, para la que fue nombrado por Resolución INT/774/2017, de 11 de abril (BOE, núm. 262, de 28 de octubre de 2017). 
- Resolución de 27 de octubre de 2017, de la Presidencia del Senado, por la que se publica el Acuerdo del Pleno del Senado por el que se aprueban las medidas requeridas por el Gobierno, al amparo del art. 155 de la Constitución (BOE, núm. 259, de 27 de octubre de 2017).

- Orden PRA/1034/2017, de 27 de octubre, por la que se publica el Acuerdo del Consejo de Ministros de 21 de octubre de 2017, por el que, en aplicación de lo dispuesto en el art. 155 de la Constitución, se tiene por no atendido el requerimiento planteado al M. H. Sr. presidente de la Generalitat de Cataluña, para que la Generalitat de Cataluña proceda al cumplimiento de sus obligaciones constitucionales y a la cesación de sus actuaciones gravemente contrarias al interés general, y se proponen al Senado para su aprobación las medidas necesarias para garantizar el cumplimiento de las obligaciones constitucionales y para la protección del mencionado interés general $(B O E$, núm. 259, de 27 de octubre de 2017).

- Real Decreto-ley 15/2017, de 6 de octubre, de medidas urgentes en materia de movilidad de operadores económicos dentro del territorio nacional (BOE, núm. 242, de 7 de octubre de 2017).

- Real Decreto 897/2017, de 6 de octubre, por el que se regula la figura del consumidor vulnerable, el bono social y otras medidas de protección para los consumidores domésticos de energía eléctrica $(B O E$, núm. 242, de 7 de octubre de 2017).

- Ley 5/2017, de 29 de septiembre, por la que se modifica la Ley 17/2006, de 5 de junio, de la radio y la televisión de titularidad estatal, para recuperar la independencia de la Corporación RTVE y el pluralismo en la elección parlamentaria de sus órganos $(B O E$, núm. 236, de 30 de septiembre de 2017).

- Real Decreto 728/2017, de 21 de julio, por el que se aprueba el Reglamento de adquisición y pérdida de la condición de guardia civil y de situaciones administrativas del personal de la Guardia Civil (BOE, núm. 181, de 31 de julio de 2017).

- Real Decreto 772/2017, de 28 de julio, por el que se regula el potencial de producción vitícola (BOE, núm. 180, de 29 de julio de 2017). 